\title{
Remembrances of Empires Past
}

\author{
Robert Aldrich, University of Sydney
}

Half a century has passed since the era of colonialism turned into the age of decolonisation. Most of the Asian possessions of Britain, the Netherlands, the USA and France gained independence in the decade after the Second World War, and independence came to the majority of countries in northern and sub-Saharan Africa in the following ten years, from the mid-1950s to the mid-1960s. From the late 1960s, the smaller island territories of the Caribbean, the Indian Ocean and the Pacific followed suit. The onset of the 1990s saw what could be characterised as the decolonisation of the Soviet empire in the Baltic and Central Asia, and of the Serbian empire in the Balkans. ${ }^{1}$

This process was drawn out, ragged and, of course, incomplete. Many colonial powers held out against decolonisation-France in Algeria, the Netherlands in West Papua, the Portuguese in Africa - and the decolonisation of Rhodesia and the end of apartheid in South Africa were agonisingly long. Some fifty outposts around the world may still be considered 'colonies' of the old imperial powers, from Britain's tiny Pitcairn in the South Pacific to Denmark's giant if sparsely populated Greenland in the North Atlantic. ${ }^{2}$ Various groups around the world, including Tibetans, Tamils, Western

\footnotetext{
${ }^{1}$ For an overview, see Aldrich (2007). Two excellent recent studies of decolonisation are Thomas, More and Butler (2008), and Shipway (2008).

${ }^{2}$ See Aldrich and Connell (1998). Changing relations between metropolitan states and these residual 'mini-empires' provide a minor continuing theme in domestic and international politics. Mayotte, a French outpost in the Indian Ocean, is set to become a fully-fledged département d'outre-mer of the French Republic in 2012. The Netherlands Antilles, a group of five islands administered as a single unit, will disaggregate in October 2010: Curaçao and Sint-Maarten as semi-autonomous countries within the Kingdom of the Netherlands, and the three other islands becoming 'special municipalities' of the Netherlands.
}

PORTAL Journal of Multidisciplinary International Studies, vol. 7, no. 1, January 2010.

Fields of Remembrance, special issue, guest edited by Matthew Graves and Elizabeth Rechniewski.

ISSN: 1449-2490; http://epress.lib.uts.edu.au/ojs/index.php/portal

PORTAL is published under the auspices of UTSePress, Sydney, Australia. 
Saharans, Palestinians, Ossetians, southern Sudanese, continue to demand selfgovernment or outright sovereignty. Nevertheless, from the perspective of the great imperial powers that ruled huge overseas empires at the start of the twentieth century (Britain, France, Portugal, the Netherlands, Germany, Italy, the USA, Japan), the flags had been lowered, independence granted even if sometimes reluctantly, and a new world order more or less established by the mid-1960s. The old colonial powers could get on with other business: the economic and social modernisation championed during the trente glorieuses of the post-war boom; European integration; and the jockeying for position in the newly christened Third World. President de Gaulle memorably said that decolonisation had become French policy because it was in the French interest, and leaders elsewhere echoed those sentiments. The photographs of colonials sitting on the veranda with their long drinks in the 'good old times' faded, the 'curios' brought back from exotic places gathered dust in museums, and colonialism drifted from lived experience to memory and on into history.

Europeans, for the most part, forgot their colonies, in a fit of absence of mind, through an attack of amnesia or by wilfully erasing or occluding the colonial traces in their midst. In some instances, this proved quite literally the case. The Italians lost their empire after the Second World War, and the grandiose building Mussolini had commissioned for the Ministry of Italian Africa was given to the UN to house the Food and Agriculture Organization (FAO). The French sandblasted the names of colonial heroes from the outside of the Mauresque colonial training academy, the École Coloniale, in Paris, and for a time they closed off the Salle des Fêtes in the old colonial museum with its now dubious murals of the benefits France gave to the colonies (education, law, science); old colonialist paintings in the collection were mothballed and then shipped out to a suburban museum. In the 1970s the Dutch, for their part, redid the exhibitions at the Tropenmuseum in Amsterdam to remove references to Holland's overlordship of the East Indies, transforming a triumphalist colonial museum into an ethnographic one. The British had already closed the Imperial Institute, opened, as were similar museums, to exhibit and celebrate empire, and the new Commonwealth Institute in Kensington, with its modernist architecture and the flags of independent member states flying, aimed to symbolise a new family of nations. ${ }^{3}$

\footnotetext{
${ }^{3}$ See Aldrich $(2005 ; 2009)$ for further references.
} 
The landscape nevertheless remained littered with streets named for the great and good of colonialism, museums jam-packed with the booty of empire-in the case of London, the Benin bronzes in the British Museum, the Indian textiles in the Victoria and Albert Museum, the Orientalist paintings of the National Gallery-while war memorials, ministries where men had ruled the empire, churches from which missionaries set out to spread the gospel, and buildings decorated with exotic motifs copied from Africa or Asia, bore witness to Europe's domineering engagement with the wider world. Many of these survived despite the efforts at monumental and museographical revisionism. Two cities provide notable examples.

In Rome, inheritor of the monuments of Antiquity and capital of a modern empire, at the head of the avenue leading to the Foro Italico (itself an extraordinary stadium topped by homoerotic statues representing athletes from various corners of Italy) still stands an obelisk inscribed 'Mussolini Dux' and a series of marble plaques recounting in detail the Italian conquest of Ethiopia in the 1930s. Outside the old Ministry for Africa (now the headquarters of the Food and Agriculture Organization of the United Nations, FAO) stood until recently - more on this presently - a tall Ethiopian stele from Axum, brought back by Mussolini's troops. Just off the Piazza dei Cinquecento, near Rome's rail terminal, a passerby can still see a monument marking Italy's heroic defeat at Adwa on the horn of Africa in the 1890s. The Esposizione Universale Roma (EUR) quarter built by the Fascists contains the Pigorini Museum, many of whose ethnographical artefacts were brought back to Italy by explorers and conquerors. Modern Italy's overseas empire may not have been either extensive or long-lived compared to those of other powers, but it, too, left vestiges among the ruins of Rome. ${ }^{4}$

Near Lisbon, capital of one of the world's longest-lived imperial nations, the suburb of Belém hosts a virtual colonial theme park. The beautiful tower (the symbol of Lisbon) that guided the explorers' ships down the Tagus River to the Atlantic stands a few steps away from the Jerónimos monastery, built with the profits brought back from the Indies; inside the monastery are the tombs of the explorer Vasco Da Gama (whose statue looms over the Praça do Império outside) and the poet of exploration and world-traveller Luís de Camões (rendered Camoens in English). On the riverfront, an enormous monument to the explorers, a vestige of Antonio Salazar's 1940 exhibition of the Lusophone world,

\footnotetext{
${ }^{4}$ See von Henneberg (2004); Labanca (1992) discusses museums and other colonial-era collections.
} 
features Prince Henry the Navigator, seamen, missionaries and other figures from the cast of colonialists. Nestled behind the monastery is Lisbon's colonial botanical garden, boasting busts of Africans and Asians, colonial-inspired azulejo tilework, and a Chinese gate marking the entrance to a plot of Asian flora reminiscent of Macao. Visitors to Belém also see a more recent addition to the monumental landscape: a stark memorial to Portuguese soldiers who died in the wars of decolonisation in the 1960s and 1970sPortugal did not withdraw from its colonies until 1975-in the form of an open topped, un-triumphal arch (Léonard 1999). ${ }^{5}$

That relatively recent marker to the end of empire has joined a proliferation of other new or recycled monuments in Europe. In Germany, a monument to a colonial hero in Lübeck was rededicated in 1990 as a monument to anti-colonialism, ${ }^{6}$ emblematic of a reassessment of Germany's imperial past. Queen Beatrix in 2002 unveiled a monument in Amsterdam to slaves in the Dutch empire, and subsequently the municipal council erected a statue of the Surinamese anti-colonial activist Anton de Kom in a migrant neighbourhood of the Dutch capital. In 2005, President Chirac unveiled a monument, on the Quai Branly, to French soldiers who died in the Franco-Algerian War of 1954-1962, and in 2007, he dedicated a monument in the Luxembourg Gardens in memory of slaves and slave emancipation. Meanwhile, the Italian government, after decades of procrastination, in 2005 finally returned the Axum column, the end of a long effort by Ethiopians to repatriate the monument stymied by Italian arguments that it would be too costly or fragile to transport, that it risked harm in the midst of Ethiopia's unstable political situation, or that it was rightly now part of the Italian monumental patrimony.

Colonialism even returned to the museums. Several years ago, the Tropenmuseum reintroduced a section on Dutch colonialism, using an interesting mise en scène that thoughtfully provokes and instructs visitors by focussing on individual biographies of Dutch imperialists and Indonesian nationalists. The National Maritime Museum in Greenwich for several years had a controversial exhibition showing a genteel tea party - but with the hand of an African thrust through the floor as from the hold of a slave ship. For its current iteration of the exhibition on the Atlantic world, which

\footnotetext{
${ }^{5}$ Among other colonial lieux de mémoire in Lisbon are the museum of the Fundaçao Oriente and the Macau museum.

${ }^{6}$ On colonial vestiges and monuments in Germany, see van der Heyden and Zeller (2002), Poiger (2005), Kössler (2006), Bertout (2006), Steinmetz and Hell (2006), and Vanvugt (1998).
} 
includes a number of vitrines on slavery, the museum commissioned a Guyanese poet, John Agard, to write reflections on the various artefacts included in the display cases (2007). King Leopold's grandiose Africa Museum in Tervuren, outside Brussels, is belatedly being brought up to date. Some of the more gruesome photos of the Belgian Congo that certainly were not displayed in colonial times and for long afterwards are now mounted on the walls, and the museum, as part of a large-scale renovation now in progress, has developed a new, and critical, section on Henry Morton Stanley (whose papers the African Museum holds). A Museum of the British Empire and Commonwealth opened in Bristol in 2002, though it struggled to attract visitors; its main galleries closed in 2008, and the museum foreshadows a reopening in London. In France, with much controversy, the collections of the old Musée des Arts d'Afrique et d'Océanie (itself the old colonial museum opened in 1931) and the Musée de l'Homme (established a few years later) were combined into the new Musée du Quai Branly in 2006 . $^{7}$ The old colonial museum, somewhat paradoxically, has now become a centre on the history of immigration into France; its inaugural exhibition focussed on foreigners in France at the time of the 1931 exposition coloniale internationale for which the building was constructed. Plans for a national museum of colonial history, to be sited in Marseille, were scuppered because of arguments among those who considered themselves moral stakeholders - national and local authorities, curators and historians, and the public, including pieds-noirs and the descendants of those colonised by the French.

The case of the proposed Marseille museum is revealing about wider debates on monuments and museums with some connection with colonialism, and about 'ownership' of the colonial past. There have been vitriolic debates, in particular, around the Yasukuni War Memorial in Tokyo, the Shinto monument where the souls of the Japanese war dead, some of them convicted war criminals, are enshrined. ${ }^{8}$ The memory of the Japanese imperialist occupation of Korea and China, the 'rape of Nanking,' the 'comfort women,' and Japan's war record all remain extremely sensitive issues both in Japan and in the countries invaded by the Japanese. On the other side of the world, conflicts have erupted in the Baltic over monuments honouring Soviet soldiers as

\footnotetext{
${ }^{7}$ See Thomas (2008), Amato (2006), and 'Le moment du Quai Branly,' a special issue of Le Débat (2007).

${ }^{8}$ See Seraphim (2006), Sturgeon (2006), Hasegawa and Togo (2008), Breen (2008), and Miyoshi-Jager and Mitter (2007).
} 
liberators in the Second World War, when present-day Latvians and Lithuanians are more apt to see the forces of the USSR as armies of colonial-style conquest and occupation.

Official statements on incidents from the colonial past have accompanied the controversies of monumental commemoration. The Japanese emperor and various prime ministers have expressed regret at wartime atrocities committed by their soldiers and administrators, though never to the full satisfaction of the Chinese and Koreans. In 2004, a German minister, speaking in Namibia, made an official apology for the attempted genocide of the Herero people carried out in German South-West Africa exactly a century before. In the case of Italy, the government placed money where its mouth was; in August 2008, the government signed an agreement to pay a sum of $\$ 5$ billion (including \$200 million per annum in investment and infrastructure projects) over the next twenty-five years as compensation to Libya for the ill effects of colonialism. Meanwhile, in Australia in February 2008, Labor Prime Minister Kevin Rudd memorably said 'sorry' to the 'stolen generation' of Aborigines removed as children from their families, part of a process of national reconciliation with Australia's indigenous population that followed many years of debate on such issues as Aboriginal land rights and bitterly fought 'history wars' about a 'black armband' versus a 'white blindfold' view of Australia's colonial history (Macintyre \& Clark 2004).

These examples of present-day confrontations with the colonial past could be multiplied, both for official statements by political leaders and in the representation of colonialism in public monuments and museum collections. The record of the past and differing interpretations in words, commemorations or exhibitions today illustrate how strongly colonialism marked the landscapes, the cultures and the psyches of the colonising countries, and also how the colonial record has become an object of contemporary contention - the 'return of the colonial' (retour du colonial), as it has been referred to in France. Monuments and museums, those highly charged material repositories of collective memory in the public sphere, serve as flashpoints for issues that extend to academic debates, parliamentary acts and legal decisions, public demonstrations and even riots. Calls for official apologies underscore the ways in which symbolic gestures gain importance in the debate on the colonial record, and how the decision on whether to say 'sorry,' recognise colonial wrongs in law, and appropriate funds for 
compensation are bound up with current political, social and cultural conditions in both the former colonial powers and in the countries that were colonised. ${ }^{9}$

The colonial has reappeared in other forums as well; the audiovisual media provides a major venue for rediscovery of the empire. In France films of the early 1990s, such as Indochine (Wargnier, dir., 1992) and L'Amant (Annaud, dir., 1992), the latter adapted from Marguerite Duras's best-selling novel (1984), presented a bittersweet, nostalgic look back at the colonial period, while Pierre Schoendoerffer offered a heroic portrayal of the end of the French empire in Diên Biên Phú (1992). Bertrand Tavernier and Patrick Rotman's film documentary La Guerre sans nom (Tavernier, dir., 1992) and Bernard Favre's documentary television series for Antenne 2, 'Les années algériennes' (1991), played a major role in sparking renewed public discussion on the Algerian war of independence (1954-1962). Rachid Bouchareb's film Indigènes, the story of North African soldiers who fought for France in the Second World War, attracted enormous attention in 2006, with newspapers filled with articles about the film and the history of colonial troopers in the Liberation of France, with President Chirac reportedly so moved by a screening that he initiated revisions in administrative regulations to extend further veterans' benefits and public recognition to the old soldiers. Alain Tasma's 2005 film for television, 'Nuit noire, 17 octobre 1961,' focussed attention on the bloody suppression of a demonstration against the Algerian war in Paris on 17 October 1961, and the Austrian director Michael Haneke's prize-winning film Caché, also from 2005, looked specifically at an incident of the repression of a traumatic colonial-era memory of Algeria.

The obvious question to ask is why the colonial ghosts have returned from the past to haunt the postcolonial present at this particular time. Several of the precipitating factors are specific to individual countries, but others seem more commonly shared as part of the political, social and cultural conjuncture of our generation.

\footnotetext{
${ }^{9}$ This essay looks at European colonial countries, primarily France, but there have also been reappraisals of colonialism in the former colonies. In recent years, for example, Algeria has allowed a conference to be held on the pied-noir Nobel Prize-winning writer Albert Camus, a monument with statues of French and African First World War soldiers, 'Demba et Dupont,' has been reconsecrated in Dakar, and the government of the Ivory Coast built a grandiose mausoleum for the remains of Pierre Savorgnan de Brazza, credited with the French conquest of the country.
} 
Perhaps one banal reason for the re-examination of the colonial past has been the commemoration of anniversaries. In Spain, in the Hispanophone world and in North America, the quinto centenario of Columbus's voyages led to heated arguments about explorers and conquest, indigenous populations and settlers. The five hundredth anniversary of the voyages to the Indian Ocean and Brazil of the Portuguese mariners Da Gama and Cabral initiated similar commemorations of the 'discoverers' (as they were always called), though with seemingly less attention paid to the colonial aftereffects of exploration. The four hundredth anniversary of the Dutch East India Company in 2002 was marked widely in Holland, and scholars have published analyses of exactly how that occasion was celebrated (Oostindië 2003; Blussé 2003). The two hundredth anniversary of the end of the slave trade in 2007 led to various commemorations and reassessments in Britain and other countries involved in slavery. ${ }^{10}$ The fiftieth anniversary of the end of the Indochinese war precipitated a spate of books and articles in France. ${ }^{11}$ One might speculate on the exact role of anniversaries in the cycles of historical study and public debate, but it seems clear that they provide what are at least convenient opportunities for historical and political stock-taking.

Historical work also prompted reassessments of the colonial heritage, although with a certain chicken-and-egg aspect to the links between public events and academic research. ${ }^{12}$ Colonial history has experienced a great revival in the last couple of decades, in what amounts to a resurrection of a field once considered as dead as the empire. The opening of archives (in many cases, thirty years after the events that occurred at the time of imperial retreat) has provided new primary sources. Edward Said's crucial book Orientalism (1978) played a revolutionary role in turning the historian's gaze to imperial encounters, even if many historians disagree with his sweeping conclusions. ${ }^{13}$ The 'cultural turn' in scholarship focussed attention on the broadly cultural history of empire, with countless books on images, clothing, food, music, landscape. Innovative themes of the 'new colonial history' include colonial medicine, colonialism and the environment, and gender and colonialism. The emergence of postcolonial studies produced a field of great influence; even when many historians express reservations

\footnotetext{
${ }^{10}$ On the commemoration of slavery, see Wallace (2006), Reinhardt (2006), Vergès (2006), Bongie (2001), and Schmidt (1999).

${ }^{11}$ See Ruscio and Tignères (2005) and Cooper (2004).

${ }^{12}$ The most perceptive analysis of the linkage between history writing and politics, and the use of the colonial past, is Coquery-Vidrovitch (2009).

${ }^{13}$ For instance, see the critique by Mackenzie (1995).
} 
about the methods it used and the generalisations advanced, postcolonial studies has posed challenges about how to read the colonial archive and how to think through the history of colonial contacts. More recently, perhaps suggesting another turn in historiography, interest has revived in more traditional topics such as the history of law, citizenship and institutions, as well as the economic history of empire. Other current approaches, such as trans-national, international and global history, have also focused on colonialism and its aftermath. All of these perspectives have produced a more nuanced and comprehensive inquiry into the phenomenon of colonialism, illustrating the extent to which colonial expansion permeated metropolitan life and revealing how European knowledge, attitudes and policies in many previously unappreciated ways were formed in a colonial context. The new scholarship has also identified the significant and enduring connections between the colonial past and the present.

Colonialism, for most specialists, made a major impact both on the societies that were conquered and on the colonising states. Though expansion never enjoyed a consensus of support, a wide range of people were involved in empire. It inflected political debates, and both made and broke political careers. It provided opportunities for commercial profit, contributed to new academic disciplines from Egyptology to anthropology, provided the terrain for missionaries, educators, engineers and others hoping to 'civilise' the peoples of the wider world, and inspired trends in art and literature, food and fashion. The end of empire left scars in national memory, and the sometimes conflicted relationship between the colonising countries and the former colonisers continues to influence international relations. ${ }^{14}$

Historical research has coincided with the 'outing' of old colonial memories, and the old skeletons tumbling from the closet have sparked new controversies. In the case of France, in the year 2000, interviews given to the press by a superannuated general, Paul Aussaresses, offered shocking revelations about the practice of torture by French troops in the Algerian War. Although writers at the time, notably Henri Alleg in La Question (1958), had alerted the French public to such practices, Aussaresses's fresh revelations, coupled with his own seeming lack of remorse, led to much public debate and historical investigations on torture in the colonies (Aldrich 2006). Research on the Mau Mau

\footnotetext{
${ }^{14}$ On the British case, see Thompson (2005), though Porter (2004) provides a somewhat different view. On France, see Lebovics (2004).
} 
rebellion, revisited in a Pulitzer Prize-winning study by Carolyn Elkins (2005) that drew on the reminiscences of participants, reminded the British of a not always glorious record of peaceful decolonisation. Adam Hochschild's (1998) exposé of the brutal Belgian colonialism in the Congo caused an uproar when it appeared in Belgium in the late 1990s. In Italy, Angelo Del Boca's Italiani, brava gente?, published in 2005, challenged the memory of Italians as largely benign colonisers, and a volume by a journalist, Eric Salerno, charged Italians with Genocidio in Libia (2005).

History and memory are different realms, of course, but mention of memory points to the role of identity politics, and what might be called 'communitarian commemoration,' in the return of the colonial. This connects with various forms of militancy, the politicisation of colonial history, and the manipulation (or instrumentalisation) of colonial issues for present-day political purposes. In some cases, particular groups have sought acknowledgement for colonial deeds or misdeeds. Returned soldiers in France long campaigned, with no success until 1999, for the Algerian conflict to be declared a 'war,' and thus for recognition of their status as fully-fledged anciens combattants. The harkis, Muslims who fought with the French in the Algerian War, similarly claimed acknowledgement, not only of their war service, but of their mistreatment in France, where many who had fled their homeland (as many others were being killed by the victorious nationalists) languished in resettlement camps until the 1970s. The descendants of slaves campaigned with success, in 2001, for a declaration by the French parliament (in the loi Taubira) that slave-trading and slavery constituted 'crimes against humanity.' 15

At one extreme, this militancy can become historically revisionist, even negationist, as when some pieds-noirs in France call for the rehabilitation of the diehard defenders of Algérie française who turned to terrorism. The Organisation Armée Secrète (OAS) burned the city library in Algiers, attempted scorched-earth tactics to keep 'French' infrastructure from being passed on to Algerians, and even tried to assassinate de Gaulle; extremist groups in France have recently been trying (with occasional success) to erect monuments in memory of OAS terrorists executed by the French state, whom they see as martyrs. On the other side, groups such as Les Indigènes de la République

\footnotetext{
${ }^{15}$ Among a number of works on the memory of colonialism in France, see Blanchard, Bancel and Lemaire (2005), Bertrand (2006), Lorcin (2006), Jahan and Ruscio (2007), and Stora and Hémery (2007).
} 
have intentionally used polemical rhetoric to popularise their arguments about the plight of migrants and their descendants in French society, and some journalists and other writers prove quick to link almost any present-day issue to the evils of the colonial past. Community groups throughout Europe, radical or more moderate, have thus taken a lead in returning colonialism to widespread public attention, especially when they are able to use media savvy to spread the word. The internet, in particular, has provided a powerful forum for airing views, with a proliferation of sites expressing the remonstrances of groups with some brief linked to colonial questions, spanning the spectrum from the far left to the extreme right.

The presence of many populations in Europe with colonial antecedents, it goes almost without saying, and their rising militancy, constitute additional reasons for the rediscovery of colonialism. Many settlers poured back into Europe after the end of the colonial empires - a million pieds-noirs, but (as is less well known) also over half a million Portuguese and mixed-race people from Portugal's empire, and 250,000 Dutch, Eurasian and pro-Dutch people from the East Indies. Largely quiescent at first, over recent years these groups, ageing first-generation migrant cohorts, have striven to secure their reputation and heritage, record their memories and histories, and gain redress for lingering grievances. Such efforts have extended to those who thought themselves unthanked servants of the empire, such as the harkis in the case of France, and the Gurkha veterans of Britain's imperial army (who in May 2009 gained the right of abode in Britain thanks partly to the energetic work of Joanna Lumley). In 2007, another colonial group, the Ilois, scored a court victory in London as well; these former residents of Diego Garcia displaced to Mauritius when London decided to rent the British Indian Ocean Territory to the USA as a military base, gained recognition of their status and the right of return, though a quick repatriation seems unlikely.

The Gurkhas and Ilios are numerically small populations, but the declining years of empire witnessed an accelerated large-scale migration that subsequently continued. Authorities in the years of decolonisation and soon afterwards, which coincided with an economic boom in Europe, sought cheap subaltern labourers from the empire, and continued to favour migration from the former colonies. These migrants now make up substantial communities in Europe, especially North Africans and black Africans in France, South Asians in Britain, and West Indians in both countries and in the 
Netherlands. Their experiences have varied, with a number of notable successes by migrants who have achieved fame and fortune in Europe, but the failed economic advancement, and social and cultural incorporation of a large proportion of these 'colonial' migrants, have been painfully apparent. Particular incidents have illuminated clashes between migrant groups and the wider society: in France, the affaire du foulard around 2004 and then the rioting in the banlieues $^{16}$; in Britain, riots in Notting Hill and Brixton; in Spain, Italy and elsewhere, the issue of clandestine arrivals from North Africa. Everywhere, especially since ' $9 / 11$ ' and the later terrorist attacks in London and Madrid, the question of Islamism in Europe has arisen, accompanied by the charge, or fear, that a potentially violent and anti-Western Islam finds a congenial home among the disenchanted descendants of migrants from the old colonies to the European metropoles.

In a less catastrophic sense, heightened communitarianism and militancy among marginalised groups have challenged the structures and ideologies of national life. This is particularly the case in France, which has the largest Muslim population in Europe. Yet the republican values of universalism and laïcité, for better or worse, create strict limits to expressions of particularistic cultural identities, such as the wearing of traditional head-scarves (and, even more so, burqas) by Muslim women, even when that policy aims to ensure liberty of belief and behaviour as well as separation between church and state. The republican virtue of egalitarianism forbids preferential treatment, or positive discrimination, with the result that those issuing from the working class or migrant milieux (and women) remain substantially underrepresented at the highest echelons of the state, private business and education. Reaction against migrants from xenophobic groups has also threatened to replace the sacrosanct fraternité proclaimed in the slogan of the revolution. And the very existence of an increasingly variegated mosaic of residents from diverse backgrounds has launched a debate on what it means to be French.

Contemporary problems in Europe, such as migration, unemployment, social unrest and integration of diverse populations, often relate more to social and economic conditions than to ethnic background or a direct colonial legacy. Therefore, analytical links between these problems and colonialism need to be drawn very prudently; but the point is that contemporary problems are seen by many to have roots in the actions and

${ }^{16}$ Among a burgeoning number of works on migration and multiculturalism in France, see Winter (2008). 
ideologies of colonialism, the conduits of migration opened by colonial population movements, and the unresolved questions of national identities and policies created by postcolonial heritages. Individuals and lobby groups of all political persuasions can evoke such connections for electoralist and demagogic purposes. The links that they easily make underline the way in which it is possible, dangerously, to draw on fears induced by the postcolonial demographic make-up of European countries-from Enoch Powell's 'rivers of blood' in 1960s Britain to latter-day manifestations, such as Pim Fortuyn's political campaigns (leading to his murder) in the Netherlands, Jean-Marie Le Pen's National Front movement in France and the British National Party-all with platforms based on opposition to migration (especially from the old colonies and from outside Europe) and multiculturalism. On the other side of the ideological spectrum, the imputation that all of the problems of contemporary European societies or of their 'ethnic' populations, as well as the problems of the developing and formerly colonised world, stem from colonial, neo-colonialist and postcolonialist ideas and policies makes for a simplistic and ultimately unconvincing analysis of the state of particular nations and the world in general.

Debates on the colonial legacy have nevertheless occasionally taken on aspects of polemics and provocation, with dramatic interventions by politicians and parliamentarians, as has notably occurred in France. The Aussaresses affaire in France that began in 2000 led to a number of carefully documented works on the use of systematic torture in Algeria, and other exposés of colonial crimes and excesses. To some, this seemed an attempt (often blamed on 'leftist' journalists, historians and politicians) to impugn the integrity of the French state, the institution of the army, the soldiers who had served in North Africa and the settlers of Algérie française. In 2005, députés in the right-wing dominated parliament adopted a law paying homage to French settlers in North Africa with an article mandating the teaching of the 'positive role' of colonialism, a provision that caused such an outcry that the Algerian president accused the French of 'negationism' (a term generally applied to denial of the Holocaust), and historians organised petitions and demonstrations against the interference of parliamentarians in the teaching of history. President Chirac ultimately was pressured to abrogate the specific article. However controversy continued over the interpretation of the imperial balance-sheet when Chirac's successor, Nicolas Sarkozy, delivered a speech in 2007 in Dakar (capital of the former French West Africa), which seemed an 
apologia for colonialism. The speech caused an angry response in Africa and in France (Gassama et al. 2008; Ba Konaré 2008; Chrétien 2008), and several prominent historians collaborated on a book on Sarkozy's misuse of history (de Cock et al. 2008). Not only did the reactions underline the divisive and sensitive nature of pronouncements about colonialism, especially if considered unreasoned (rightly or wrongly), they also raised questions about whether the statements of politicians or 'memory laws' passed by parliaments advance either real understanding of the phenomenon of colonialism or lead to any sort of national or international reconciliation or justice.

'Colonialism' as an area of history and an object of debate represents a broadly based and long-lived movement that involves traders and missionaries, soldiers and settlers, bureaucrats and adventurers. It encompasses European actions overseas and the emergence of colonial interests and a colonial culture at home, support for expansion but also continued opposition to colonialism, the mission civilisatrice and the export of European notions of constitutionalism, parliamentarianism, revolution and socialism that ultimately contributed to the undoing of empires. Even as the number of those with a personal experience or memory of empire inevitably dwindles in Europe, many are those whose lives colonialism touched. The French population, for example, includes the descendants of several thousand Vietnamese refugees who arrived after the defeat in Indochina in 1954, and the million pieds-noirs 'repatriated' to the mainland, along with around 90,000 harkis and their families, in 1962. Many now retired French men and women served overseas in one or another capacity; some of the most prominent French cultural figures of the last generation, from Fernand Braudel to Pierre Bourdieu, had formative experiences in the colonies. More than a million French conscripts fought in the Algerian War. Millions of migrants to France and their descendants claim ancestral ties with countries colonised by France, and 2.5 million French citizens now live in the outposts that still form part of the Republic.

The effects of that colonial heritage do not necessarily dominate the personal lives and daily activities of every French man or woman with some link to colonialism-or those in Britain, Portugal or other countries with a similar connection - but as Frantz Fanon (1952) and Albert Memmi (1957) showed long ago, colonialism impressed a longlasting psychological imprint onto those whom it affected, from bitter rapatriés and invalided returned soldiers to migrants from the Antilles, the Maghreb and sub-Saharan 
Africa seeking a better life in France. It would take a psycho-historian to analyse the emotional dimensions of the retour $d u$ colonial, but the psychological implication is clear in language about the 'trauma' of colonialism and the 'scars' and 'wounds' that it left, in the need for certain groups to position themselves as victims, in openly expressed fears about national decline and a dissolution of an idealised national identity, and in calls for (or opposition to) repentance for the misdeeds of the colonial past. ${ }^{17}$ In both reality and perception, many feel colonialism and the attitudes of the colonial age to be pertinent to their contemporary situations and problems.

Many European countries are products of their recent or more distant colonial past, though undoubtedly to greater and lesser degrees. To take, once again, the example of France: for hundreds of years, and especially from 1830 to 1962, the French nation and state were conjoined with an overseas empire, and imperialism formed part of the nation-building project, France and la plus grande France, the greater France that at its apogee encompassed 11 million square kilometres of territory and 100 million citizens and subjects. France's economic prosperity and geopolitical influence, several generations of colonialists told their compatriots, depended on the conquest and mise en valeur of colonies. France's culture and ideals were universalistic, colonial boosters added, a mandate and a legitimisation for the expansion of that culture. Since the early 1960s, by contrast, nation-building in France has meant the construction of a nation without an empire.

Yet France never abandoned its 'imperial' ambitions, underpinned with often neocolonial relations with former colonies, nurturing of privileged links with Francophone countries, supplies of cheap labour from the former possessions, and the maintenance of a dozen overseas outposts that provided sites for nuclear testing, space exploration and the rayonnement of French culture. President de Gaulle positioned himself as the great decoloniser, and his successors posed as champions of the Third World, intermediaries between the North and South and, during the Cold War, between the East and West. Such leverage, along with France's economic strength, its place on the UN Security Council, its role in the European Union and other advantages, secured grandeur after the end of empire. Since the mid-1990s, however, this postcolonial structure has begun to come apart with the end of the Cold War, the rise of Islamism, the crisis in

\footnotetext{
${ }^{17}$ Moreover, the notion of 'repentance' touches on religious practices.
} 
Françafrique, ${ }^{18}$ the rapid advance of China and the Asian economies in general, the final triumph of English over French as the international lingua franca, and the globalisation that the French have often seemed to resist rather than to capitalise on. Meanwhile, at home, persistently high unemployment, fears of economic decline and budgetary collapse, the reconfiguration of the political landscape, the debate around migration and multiculturalism, and soul-searching about 'national identity' have further disoriented a country no longer anchored by even the tenuous points of reference of the postcolonial order set in place from the 1960s through the 1980s.

The retour $d u$ colonial does not thus consist solely in the simple recovery of the history of a lost empire, or even the issue of 'memory politics' evidenced by laws, monuments and rhetoric, or the moral imperative of a devoir de mémoire, a duty to recall the bad as well as the good. It relates to the individual, collective and national experiences of colonialism and its aftermath, and it takes places within the context of the tectonic transformations of domestic and international politics. The retour $d u$ colonial does not just affect France, even if the experience has been more acute there because of the importance of empire in French nation-building (it had, after all, the world's second largest empire), France's reluctance to decolonise and the fratricidal violence of decolonisation in Algeria, and the disaggregation of a postcolonial order that France installed after the fall of the empire.

The colonial legacy is mightily present throughout contemporary Europe, particularly so for those countries that claimed overseas empires, but, in fact, is present for all European countries in the context of international migration, relations between Europe and its neighbours across the Mediterranean and further afield, and social relations in ethnically diverse and fractious societies. For a generation, most Europeans (at least those of a European ancestral background) largely tried, publicly, to forget the colonial past, or remembered it only through the rose-coloured lenses of nostalgia. Now the pendulum has swung towards a greater remembering of that past—in the views of some, to a surfeit of memory, where each group agitates for its own version of history,

\footnotetext{
${ }^{18}$ The notion of Françafrique is associated with the works of François-Xavier Verschave, such as $L a$ Françafrique: le plus long scandale de la République (1999). On France's partial disengagement from Africa, see Smith (2010), who dates the change to 1994, the year of the devaluation of the French African franc, France's non-intervention in the genocide in Rwanda (and its support for the Hutus there), and the death of one of its longest-lived African supporters, Félix Houphouët-Boigny, president of the Ivory Coast.
} 
recognition in laws and ceremonies, commemoration in museums and monuments, and the valorisation or repatriation of its art and artefacts. Words such as 'invasion,' 'racism' and 'genocide' are emotional terms that provoke emotional reactions. Whether leaders should apologise for wrongs of the past (and which wrongs, and indeed which leaders) remains a highly sensitive issue. The 'return of the colonial' thus has to do with ethics and politics as well as with history, linked to apologies, legislation, compensation, repatriation of objects, and perhaps most importantly redefinition of national identities and social policies (Barkan \& Karn 2006). The colonial flags may have been lowered, but many barricades seem to have been raised. The retour $d u$ colonial is not just a rediscovery of a lost chapter of Europe's history, but also an instigation to reevaluate the future political, social and cultural contours of countries still shaped by the colonial experience. Empire has a long after-life.

\section{Reference List}

Agard, J. 'Atlantic Worlds Poems.' National Maritime Museum, Greenwich, UK. Online, available: http://www.nmm.ac.uk/visit/exhibitions/on-display/atlantic-worlds/other-views/ [Accessed January $12010]$.

Aldrich, R. 2005, Vestiges of the Colonial Empire in France: Museums, Monuments and Colonial Memories. Palgrave Macmillan, London. 2006, 'Coming to Terms with the Colonial Past: The French and Others,' Arts: The Journal of the Sydney University Arts Association, vol. 28, 91-116. (ed.) 2007, The Age of Empires. Thames \& Hudson, London. 2009, 'Colonial Museums in a Postcolonial Europe,' Africa and Black Diaspora: An International Journal, special issue on 'Museums in Postcolonial Europe,' (ed.) D. Thomas, vol. 2, no. 2 (July), 137-56.

Aldrich, R. \& Connell, J. 1998, The Last Colonies. Cambridge University Press, Cambridge.

Alleg, H. 1958, La Question. Éditions de Minuit, Paris.

Amato, S. 2006, 'Quai Branly Museum: Representing France after Empire,' Race and Class, vol. 47, no. $4,46-65$.

Annaud, J-J. (dir.) 1992, L'Amant (1992), motion picture, TF1 Vidéo.

Ba Konaré, A. (ed.) 2008, Petit précis de remise à niveau sur l'histoire africaine à l'usage du président Sarkozy. La Découverte, Paris.

Barkan, E. \& Karn, A. (eds) 2006, Taking Wrongs Seriously: Apologies and Reconciliation. Stanford University Press, Stanford.

Bertout, V. 2006, 'Mémoires et stratégies politiques: Les commémorations culturelles Herero en Namibie,' Politique africaine, no. 102, 67-84.

Bertrand, R. 2006, Mémoires d'empires: La controverse autour du “fait colonial.” Éditions du Croquant, Paris.

Blanchard, P., Bancel, N. \& Lemaire, S. (eds) 2005, La Fracture coloniale: La société française au prisme de l'héritage colonial. La Découverte, Paris.

Blussé, L. 2003, 'Four Hundred Years On: The Public Commemoration of the Founding of the VOC in 2002,' Itinerario, vol. 27, no. 1, 79-91.

Bongie, C. 2001, 'A Street Named Bissette: Nostalgia, Memory, and the Cent-Cinquantenaire of the Abolition of Slavery in Martinique (1848-1998),' South Atlantic Quarterly, vol. 11, no. 2, 215-57.

Bouchareb, R. (dir.) 2006, Indigènes, motion picture, Mars Distribution.

Breen, J. (ed.) 2008, Yasukuni, the War Dead, and the Struggle for Japan's Past. Columbia University Press, New York. 
Chrétien, J-P. (ed.) 2008, L'Afrique de Sarkozy: Un déni de l'histoire, Karhala, Paris.

de Cock, L., et al., 2008, Comment Nicholas Sarkozy écrit l'histoire de France. Éditions Agone, Marseille.

Cooper, N. 2004, 'Dien Bien Phu: Fifty Years On,' Modern and Contemporary France, vol. 12, no. 4, 445-58.

Coquery-Vidrovitch, C. 2009, Enjeux politiques de l'histoire coloniale. Éditions Agone, Paris.

Del Boca, C. 2005, Italiani, brava gente? Editore Neri Pozza, Turin.

Duras, M. 1984, L'Amant. Éditions de Minuit, Paris.

Elkins, C. 2005, Britain's Gulag: The Brutal End of the Empire in Kenya. Jonathan Cape, London.

Fanon, F. 1952, Peau noire, masques blancs. Éditions de Seuil, Paris.

Favre, B. (dir.) 1991, 'Les années algériennes,' 3 part documentary television series, Antenne 2.

Gassama, M., et al. 2008, L'Afrique répond à Sarkozy: Contre le discours de Dakar. Philippe Rey, Paris.

Haneke, H. (dir.) 2005, Caché, motion picture, Les Films du Losange.

Hasegawa, T. \& Togo, K. 2008, East Asia's Haunted Present: Historical Memories and the Resurgence of Nationalism. Praeger Security International, Westport, CN.

Hochschild, A. 1998, King Leopold's Ghost: A Story of Greed, Terror, and Heroism in Colonial Africa. Mariner Books, Boston.

Jahan, S. \& Ruscio, A. (eds), 2007, Histoire de la colonisation: Rehabilitations, falsifications et instrumentalisations. Les Indes Savantes, Paris.

Kössler, R. 2006, 'La Fin d'une amnésie? L'Allemagne et son passé colonial depuis 2004,' Politique africaine, no. 102, 50-66.

Labanca, N. 1992, L'Africa in vitrina: Storie di musei e di exposizioni coloniali in Italia. Pagus, Paese.

Lebovics, H. 2004, Bringing the Empire Back Home: France in the Global Age. Duke University Press, Durham, NC, \& London.

'Le moment du Quai Branly.' 2007, special issue of Le Débat, no. 147 (novembre-décembre).

Léonard, Y. 1999, 'Le Portugal et ses “sentinelles de pierre”: L'exposition du monde portugais en 1940,' Vingtième siècle, no. 62, 27-37.

Lorcin, P. M. E. (ed.) 2006, Algeria and France, 1800-2000: Identity, Memory, Nostalgia. Syracuse University Press, Syracuse.

Macintyre, S. \& Clark, A. 2004, The History Wars. New edition. Melbourne University Press, Melbourne.

Mackenzie, J. 1995, Orientalism: History, Theory and the Arts. Manchester University Press, Manchester.

Memmi, A. 1957, Portrait du colonisé précédé du portrait du colonisateur. Éditions Buchet/Chastel, Paris.

Miyoshi-Jager, S. \& Mitter, R. (eds) 2007, Ruptured Histories: War, Memory, and the Post-Cold War in Asia. Harvard University Press, Cambridge, MA.

Le musée du quai Branly website. 2005, Online, available: http://www.quaibranly.fr [Accessed 26 April 2009].

Oostindië, G. J. 2003, 'Squaring the Circle: Commemorating the VOC after 400 Years,' Bijdragen tot de Taal-, Land en Volkenkune, vol. 159, no. 1, 135-61.

Poiger, U. A. 2005, 'Imperialism and Empire in Twentieth-Century Germany,' History and Memory, vol. 17 , no. $1-2,117-43$.

Porter, B. 2004, The Absent-Minded Imperialists: Empire, Society, and Culture in Britain. Oxford University Press, Oxford.

Reinhardt, C. A. 2006, Claims to Memory: Beyond Slavery and Emancipation in the French Caribbean. Bergahn Books, New York.

Ruscio, A. and Tignères, S. 2005, Dien Bien Phu, mythes et réalités, 1954-2004: Cinquante ans de passions françaises. Les Indes Savantes, Paris.

Said, E. 1978, Orientalism. Routledge \& Kegan Paul, London.

Salerno, E. 2005, Genocidio in Libia: Le atrocità nascoste dell'avventura coloniale italiana (1911-1931). Manifestolibri, Rome.

Schmidt, N. 1999, 'Commémoration, histoire et historiographie. A propos du 150e anniversaire de l'abolition de l'esclavage dans les colonies françaises,' Ethnologie française, vol. 29, no. 3, 45360.

Schoendoerffer, P. (dir.) 1992, Diên Biên Phú, motion picture, AMLF.

Seraphim, F. 2006, War Memory and Social Politics in Japan, 1945-2005. Harvard University Asia Center, Cambridge, MA.

Shipway, M. 2008, Decolonization and its Impact: A Comparative Approach to the End of the Colonial Empires. Blackwell, Oxford.

Steinmetz, G. \& Hell, J. 2006, 'The Visual Archives of Colonialism: Germany and Namibia,' Public Culture, vol. 18, no. 1, 147-83. 
Smith, S. W. 2010, 'Nodding and Winking,' London Review of Books, vol. 32, no. 3 (11 Feb.), 10-12.

Stora, B. \& Hémery, D. (eds) 2007, Histoires coloniales: Héritages et transmissions. Centre Pompidou, Paris.

Sturgeon, W. D. 2006, Japan's Yasukuni Shrine: Place of Peace or Place of Conflict? Regional Politics of History and Memory in East Asia. Dissertation.com, Boca Raton, FL.

Tasma, A. (dir.) 2005, Nuit noire, 17 octobre 1961, motion picture, Canal+.

Tavernier, B. (dir.) 1992, La guerre sans nom, motion picture, Neuf de Coeur.

Thomas, D. 2008, 'The Quai Branly Museum: Political Transition, Memory and Globalization in Contemporary France,' French Cultural Studies, vol. 19, no. 2, 141-57.

Thomas, M., More, B. \& Butler, L. J. 2008, Crises of Empire: Decolonization and Europe's Imperial States, 1918-1975. Hodder Education, London.

Thompson, A. 2005, The Empire Strikes Back? The Impact of Imperialism on Britain from the MidNineteenth Century. Longman, Harlow, UK.

van der Heyden, U. \& Zeller, J. (eds) 2002, Kolonial Metropole Berlin: Eine Spurensuche. Berlin Edition, Berlin.

Vanvugt, E. 1998, De maagd en de soldaat: Koloniale monumenten in Amsterdam en elders. J. Mets, Amsterdam.

Vergès, F. 2006, La Mémoire enchaînée: Penser l'esclavage aujourd'hui. Albin Michel, Paris.

Verschave, F-X. 1999, La Françafrique: Le plus long scandale de la République. Stock, Paris.

von Henneberg, K. 2004, 'Monuments, Public Space, and the Memory of Empire in Modern Italy,' History and Memory, vol. 16, no. 1 (Spring-Summer), 37-85.

Wallace, E. K. 2006, The British Slave Trade and Public Memory. Columbia University Press, New York. Wargnier, R. (dir.) 1992, Indochine, motion picture, Bac Films.

Winter, B. 2008, The Hijab and the Republic: Uncovering the French Headscarf Debate. Syracuse University Press, Syracuse. 